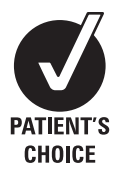

See Editorial Commentary, p 237

'Department of Neurology, St Vincent's University Hospital and University College Dublin, Ireland

${ }^{2}$ School of Public Health and Population Science, University College Dublin, Ireland ${ }^{3}$ Department of Metabolism, St Vincent's University Hospital, Dublin, Ireland

${ }^{4}$ National Histocompatibility and Immunogenetics Reference Laboratory, National Blood Centre, Dublin, Ireland

\section{Correspondence to}

Dr R Lonergan, Department of Neurology, St Vincent's University Hospital, Elm Park, Dublin 4, Ireland; roisin.lonergan@st-vincents.ie

Received 13 June 2010 Revised 2 November 2010 Accepted 3 November 2010 Published Online First 19 January 2011

\title{
Multiple sclerosis prevalence in Ireland: relationship to vitamin $D$ status and HLA genotype
}

\author{
R Lonergan, ${ }^{1} \mathrm{~K}$ Kinsella, ${ }^{1} \mathrm{P}$ Fitzpatrick, ${ }^{2} \mathrm{~J}$ Brady, ${ }^{3} \mathrm{~B}$ Murray ${ }^{3} \mathrm{C}$ Dunne, ${ }^{4} \mathrm{R}$ Hagan, ${ }^{4}$ \\ M Duggan, ${ }^{1}$ S Jordan, ${ }^{1}$ M McKenna, ${ }^{3}$ M Hutchinson, ${ }^{1}$ N Tubridy ${ }^{1}$
}

\begin{abstract}
Background The relationship between prevalence of multiple sclerosis (MS) and latitude may be due to both genetic and environmental factors. The hypothesis that, in Ireland, MS prevalence is increasing and that north-south differences relate to variation in serum 25-hydroxyvitamin $\mathrm{D}(25(\mathrm{OH}) \mathrm{D})$ levels was tested in this study.
\end{abstract}

Patients and methods Patients and matched control subjects were identified in counties Donegal, Wexford and South Dublin through multiple sources. Prevalence was determined. Blood samples were taken for serum 25(OH)D and serum intact parathyroid hormone measurement, and DNA was extracted.

Results Prevalence in 2007 was significantly greater in Donegal (northwest) (290.3/105, 95\% Cl 262.3 to 321.7) compared with 2001 (184.6/105; 162 to 209.5). In Wexford (southeast), there was a non-significant increase in prevalence in 2007 compared with 2001. Prevalence was significantly higher in Donegal than in Wexford (144.8/105; 126.7 to $167.8, p<0.0001)$ and South Dublin (127.8/105; 111.3 to 148.2, $\mathrm{p}<0.0001)$ Overall, mean $25(\mathrm{OH}) \mathrm{D}$ levels were low and did not differ between patients (38.6 nmol/l) and controls (36.4 nmol/l) However, significantly more patients than controls had $25(\mathrm{OH}) \mathrm{D}$ levels $<25 \mathrm{nmol} / \mathrm{l}$ (deficiency) ( $p=0.004$ ). Levels of $25(\mathrm{OH}) \mathrm{D}$ (mean $50.74 \mathrm{nmol} / \mathrm{l}$ ) were significantly higher in South Dublin (area with lowest prevalence) $(p<0.0001)$ than in Donegal or Wexford. HLA DRB ${ }^{*} 15$ occurred most frequently in Donegal (greatest MS prevalence) and least frequently in South Dublin.

Conclusion Vitamin D deficiency is common in Ireland. Latitudinal variation in MS probably relates to an interaction between genetic factors and environment (25 (OH)D levels), and MS risk may be modified by vitamin D in genetically susceptible individuals.

\section{INTRODUCTION}

Numerous studies support the hypothesis that multiple sclerosis (MS) is a multifactorial autoimmune disease arising from a complex interplay between genetic and environmental factors. The HLA-DRB1*1501 allele appears to be the predominant risk allele in northern European populations ${ }^{1}$ and the HLA DRB1*1501-DOB1*0602 haplotype confers greatest susceptibility to MS in Ireland. ${ }^{2}$ More recently, linkage to other candidate genes has been demonstrated, including interleukin 2-receptor alpha (IL2-RA), IL7-RA, ${ }^{1}$ EVI5 (ecotropic viral integration site 5$)^{3}$ and interferon alpha receptor. $^{4}$

Many environmental factors have been implicated in the aetiology of MS and may interact with genetic susceptibility. The role of the environment is supported by the distinctive geographical distribution of $\mathrm{MS}^{5-7}$ with the greatest incidences recorded at high latitudes north and south of the equator. $^{8-10}$ It is proposed that the latitudinal variation in MS prevalence is inversely related to sunshine exposure and associated vitamin D production. ${ }^{3}$ The hypothesis regarding the environmental contribution of vitamin $\mathrm{D}$ is supported by migration studies which demonstrate an association between place of early residence and MS. ${ }^{11} 12$ Geospatial analysis in North America and continental USA showed a strong negative correlation between MS distribution and ultraviolet B (UV-B) exposure. ${ }^{13} 14$ During winter at high latitudes, sun exposure does not generate any vitamin $\mathrm{D}$ and thus vitamin $\mathrm{D}$ insufficiency is common. ${ }^{14}$ Lower 25-hydroxyvitamin D $(25(\mathrm{OH}) \mathrm{D})$ levels during relapses, in addition to blunted parathyroid hormone (PTH) response, ${ }^{15}$ suggest that activated vitamin $\mathrm{D}$ may have immunomodulatory effects and influence disease activity. ${ }^{16}$ Activated vitamin $\mathrm{D}$ inhibits $\mathrm{CD} 4+\mathrm{T}$ cell and myelin basic protein specific IL17 secreting $\mathrm{T}$ cell proliferation. ${ }^{17}$ Clinically, this is supported by seasonal fluctuation in the number of relapses ${ }^{18}$ and gadolinium enhancing lesions on MRI. ${ }^{19} 20$

Few studies on the therapeutic effects of vitamin $\mathrm{D}$ in relapsing-remitting MS have been performed. There is no international consensus on optimal 25 $(\mathrm{OH}) \mathrm{D}$ levels or recommended daily intake, and the precise timing of vitamin $\mathrm{D}$ action, whether a discrete period or ongoing, remains unknown.

Recent reports suggest that MS prevalence is increasing worldwide. ${ }^{3} 2122$ The variation in prevalence with latitude was previously demonstrated in Ireland ${ }^{23}$ which at $53^{\circ}$ North lies in a high risk MS zone where there is minimal skin production of vitamin $\mathrm{D}$ between late October and late March due to attenuation of UV-B rays. Based on previous Irish studies, we know that genetic factors contribute to MS susceptibility ${ }^{2}$ but vitamin D may influence risk. We hypothesised that: (1) the latitudinal gradient in MS prevalence persists in Ireland and (2) greater MS prevalence at higher latitudes relates to lower 25(OH)D levels compared with southern areas and (3) serum $25(\mathrm{OH}) \mathrm{D}$ is lower in patients with MS than in healthy controls.

Our aims were to (1) compare the prevalence of MS in three areas in Ireland (two rural areas: counties Donegal (northern latitude) and Wexford (southern latitude); and one urban area: southeast Dublin city (intermediate latitude), (2) determine differences in serum $25(\mathrm{OH}) \mathrm{D}$ and PTH levels between MS patients in the three regions and 
between MS patients and healthy control subjects and (3) examine the frequency of HLA DRB1*15 in people with MS in northern and southern counties.

\section{PATIENTS AND METHODS}

Patients of Irish nationality with $\mathrm{MS}$ in each area (Donegal, latitude $54^{\circ} 8^{\prime}-55^{\circ} 43^{\prime}$, Wexford latitude $52^{\circ} 20^{\prime}-52^{\circ} 44^{\prime}$ and South Dublin, latitude $53^{\circ} 17^{\prime}$ ) were identified from multiple sources. The ascertainment sources included neurologists and MS nurse specialists, general practitioners, hospital physicians, public health nurses, the MS Society, pharmacies, Cheshire homes and respite facilities. Control participants, frequency matched for age and sex, were recruited in each of the three areas. The prevalence date was established as 31 December 2007. Informed consent was obtained from each participant. For patients with MS, their MS subtype was recorded ${ }^{24}$ and the Expanded Disability Status Scale was calculated. ${ }^{25}$ The diagnosis of MS was based on the revised McDonald criteria ${ }^{26}$ and, where necessary, was confirmed by referring to patients' medical notes. Control participants were recruited in each of the three areas and included spouses and relatives of people with MS in addition to unrelated volunteers. Data from the most recent National Census $^{27}$ were used to calculate prevalence. Blood samples from patients and controls were taken in winter months from December to March for serum $25(\mathrm{OH}) \mathrm{D}$ and serum PTH measurement, and for DNA extraction. A questionnaire regarding environmental factors, including past and current vitamin D supplementation and sun exposure, was completed. ${ }^{28}$ The ethics committee at St Vincent's University Hospital approved the study.

\section{Serum 25(OH)D and serum PTH analysis}

Serum $25(\mathrm{OH}) \mathrm{D}$ was measured by a competitive radioimmunoassay (Immunodiagnostic Systems Ltd, Boldon, Tyne and Wear, UK). Interassay coefficients of variations were $6.2 \%$ and $7.7 \%$ at concentrations of $28.8 \mathrm{nmol} / 1$ and $105.4 \mathrm{nmol} / \mathrm{l}$, respectively. The intra-assay coefficients of variations were $3.0 \%$ and $2.7 \%$ at concentrations of $28.9 \mathrm{nmol} / 1$ and $73.9 \mathrm{nmol} / 1$, respectively. Serum $25(\mathrm{OH}) \mathrm{D}$ levels of $<50 \mathrm{nmol} / \mathrm{l}$ were considered to be vitamin $\mathrm{D}$ insufficient and levels below $25 \mathrm{nmol} / \mathrm{l}$ were considered to be deficient. ${ }^{29}{ }^{30}$ Serum intact PTH was measured by electrochemiluminescent immunoassay on the Elecsys 1010 platform (Roche Diagnostics, Basel, Switzerland). Intra-assay CV was $<5.8 \%$ and interassay CV was $<7.1 \%$.

\section{HLA typing}

Genomic DNA was isolated from EDTA anticoagulated peripheral blood samples using the GenoM-6 (Genovision, Vienna, Austria) DNA isolation and purification system. Low resolution HLA-DRB1/3/4/5 typing was performed using the PCR sequence specific oligonucleotide probe assay (Invitrogen Dynal Biotech, Bromborough, UK). HLA types were determined using Dynal RELI-SCAN and RELI SSO PMP software.

\section{Statistical analysis}

SAS V.9 (SAS Institute Inc) was used. The Z test compared rates of MS in two areas, and the $\chi^{2}$ test was used for comparison of rates in the three areas. Win $\mathrm{PEPI}^{31}$ was used for comparison of rates. For comparison of means and proportions, the Student's $t$ test, analysis of variance and $\chi^{2}$ test were employed, and Pearson's correlation coefficient was calculated for correlation. Age standardised rates were calculated using direct standardisation, with the national population from the most recent census as the standard population. ${ }^{27}$ For all estimates, 95\% CIs were calculated.

\section{RESULTS}

\section{Prevalence}

In total, $632 \mathrm{MS}$ patients were identified in the three regions: 329 in Donegal, 173 in Wexford and 130 in South Dublin (table 1). MS prevalence on 31 December 2007 was: Donegal $290.3 / 10^{5}$ (95\% CI 238.7 to 255.5 ), Wexford $144.8 / 10^{5}$ (95\% CI 138.3 to 151.9 ) and southeast Dublin $127.8 / 10^{5}$ (95\% CI 131.6 to 146.7). Prevalence was significantly higher in Donegal than in Wexford ( $p<0.0001$ ) (see figure 1). Although the prevalence in Wexford was higher than that in South Dublin, this did not reach significance $(p=0.72)$.

Age standardised MS prevalence was: Donegal-all MS patients $257.8 / 10^{5}$ (95\% CI 253.2 to 262.4), male MS patients $157.6 / 10^{5}(95 \%$ CI 152.7 to 162.6) and female MS patients $358.3 / 10^{5}$ (95\% CI 350.3 to 366.5 ); Wexford-all MS patients $152.0 / 10^{5}$ (95\% CI 148.4 to 155.6), male MS patients $119.0 / 10^{5}$ (95\% CI 114.8 to 123.4$)$ and female MS patients $176.0 / 10^{5}$ (95\% CI 170.4 to 181.7 ); southeast Dublinall MS patients $123.2 / 10^{5}$ (95\% CI 120.0 to 126.4 ), male MS patients $84.2 / 10^{5}(95 \%$ CI 80.6 to 87.9$)$ and female MS patients $160.6 / 10^{5}$ (95\% CI 155.2 to 166.1$)$. The three counties were significantly different from each other when comparing age standardised prevalence in all MS patients $(p<0.001)$, in males with MS $(p<0.001)$ and in females with MS $(p<0.001)$.

In Donegal, MS prevalence had increased significantly since 2001; prevalence was $184.6 / 10^{5}$ in 2001 (95\% CI 162.0 to 209.5 ) and $290.3 / 10^{5}$ in 2007 (95\% CI 238.7 to 255.5$)(p=0.001)$. There was a non-significant increase in prevalence in Wexford; prevalence was $120.7 / 10^{5}$ in 2001 (95\% CI 100.6 to 143.8 ) and $144.8 / 10^{5}$ in 2007 (95\% CI 138.3 to 151.9$)(p=0.117)$. Prevalence was lowest in southeast Dublin (130.0/10 in 2007) but we did not have previous data for comparison (table 2 ). We could not compare age standardised prevalence rates over time because these data were not included in the 2001 prevalence study.

Overall, the female to male ratio in MS patients was 2.0:1. In Wexford, the ratio was 1.5:1 (2.2 in 2001), in Donegal 2.1:1 (2.48 in 2001) and in southeast Dublin 2.6:1 (no earlier data).

\section{5(OH)D and PTH levels}

Levels of $25(\mathrm{OH}) \mathrm{D}$ and PTH were determined in $329 \mathrm{MS}$ patients (61.3\% of all ascertained patients) and 226 healthy control subjects (table 3 ).

The mean level of serum $25(\mathrm{OH})$ D was similar in $\mathrm{MS}$ patients (38.6 (SD 22.5) nmol/l) and controls (36.4 (SD 16.4) $\mathrm{nmol} / \mathrm{l} ; \mathrm{p}>0.05))$. Mean $25(\mathrm{OH}) \mathrm{D}$ levels in patients in Donegal were $36.9 \mathrm{nmol} / \mathrm{l}$ (range 13-97), in Wexford $39.7 \mathrm{nmol} / \mathrm{l}(15-114)$ and in southeast Dublin $50.7 \mathrm{nmol} / \mathrm{l}$

Table 1 Demographic data of multiple sclerosis patients ascertained in each region of Ireland on 31 December 2007

\begin{tabular}{lllll}
\hline & Donegal & Wexford & South Dublin & Overall \\
\hline Mean age (years) & 46.7 & 47.9 & 49.5 & 48.0 \\
$\quad$ Range & $(21-80)$ & $(20-75)$ & $(27-89)$ & $(20-89)$ \\
F:M ratio & $2.1: 1$ & $1.5: 1$ & $2.6: 1$ & $2.0: 1$ \\
MS duration (years) & 15.3 & 14.9 & 17.2 & 15.8 \\
$\quad$ Range & $(1-54)$ & $(2-49)$ & $(1-53)$ & $(1-54)$ \\
Relapsing remitting MS (\%) & 53.3 & 47.0 & 53.1 & 51.1 \\
Secondary progressive MS (\%) & 37.6 & 43.2 & 39.2 & 39.7 \\
Primary progressive MS (\%) & 9.1 & 9.8 & 7.7 & 9.2 \\
Mean age MS onset (years) & 31.6 & 32.5 & 32.8 & 32.3 \\
$\quad$ Range & $(8-64)$ & $(14-54)$ & $(16-61)$ & $(8-64)$ \\
Mean EDSS & 3.6 & 3.9 & 3.6 & 3.7 \\
$\quad$ Range & $(0-9)$ & $(0-9)$ & $(0-9)$ & $(0-9)$ \\
\hline
\end{tabular}

MS, multiple sclerosis; EDSS, Expanded Disability Status Scale. 


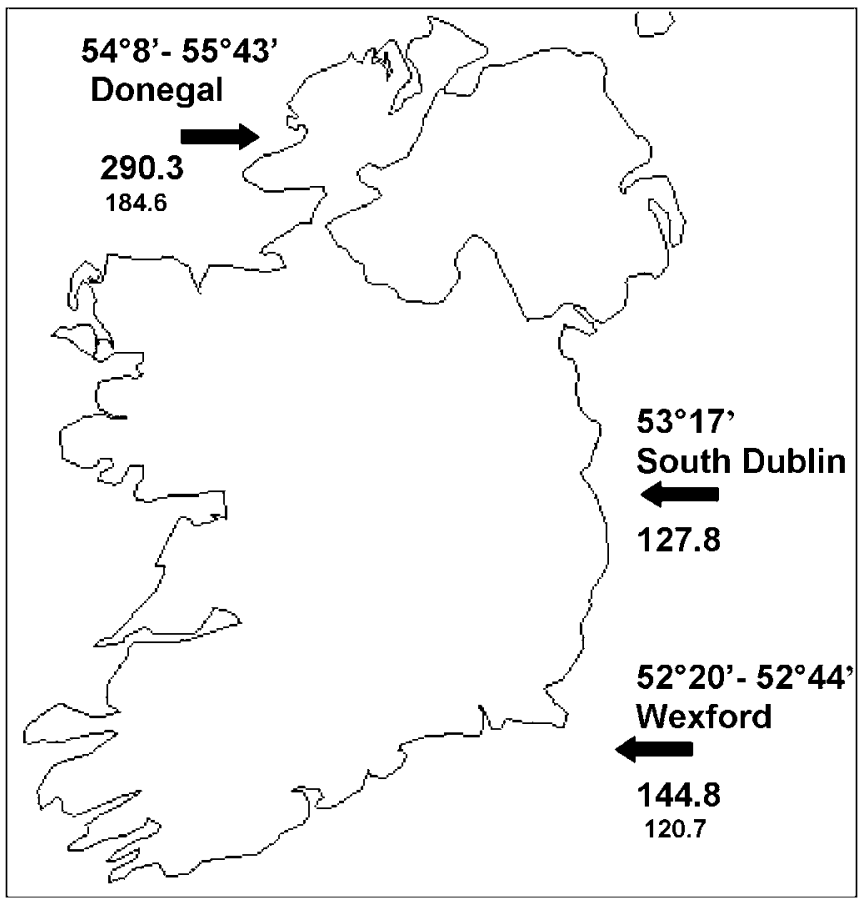

Figure 1 Map of Ireland demonstrating the three areas studied and their latitudes: Donegal county, South Dublin and Wexford county. Prevalence rate is the figure stated per 100000 population. The figure in small print below the prevalence rate is the prevalence rate in $2001 .^{23}$ There were no previous prevalence data for the South Dublin area.

(13-161). Mean levels were significantly higher in southeast Dublin, the area with the lowest MS prevalence, than in Donegal $(p<0.0001)$ and Wexford $(p<0.0001)$.

There was no significant difference between mean $25(\mathrm{OH}) \mathrm{D}$ levels in patients in Donegal and Wexford (Donegal $36.9 \mathrm{nmol} / \mathrm{l}$ and Wexford $39.7 \mathrm{nmol} / \mathrm{l} ; \mathrm{p}=0.284)$. The proportion of MS patients from all three study areas with vitamin $\mathrm{D}$ deficiency $(<25 \mathrm{nmol} / \mathrm{l})(28.3 \%)$ was significantly higher than the proportion of control subjects $(19.2 \%)(p=0.004)$.

There was a significant inverse correlation between $25(\mathrm{OH}) \mathrm{D}$ and PTH levels in MS patients $(r=-0.17 ; \mathrm{p}<0.002)$ and in controls $(r=-0.24 ; p<0.0003)$. Vitamin D deficiency $(<25 \mathrm{nmol} / \mathrm{l})$ was observed in 93 patients (28.3\%) with a mean of $20.3 \mathrm{nmol} / \mathrm{l}$ (range 13.3-24.6) and a mean PTH of $44.8 \mathrm{ng} / \mathrm{l}$ (range 16.7-86.3). There was a non-significant inverse correlation between $25(\mathrm{OH}) \mathrm{D}$ and PTH in this group of patients $(\mathrm{p}=0.28)$. Vitamin D deficiency $(<25 \mathrm{nmol} / \mathrm{l}$ ) was observed in 44 control subjects (19.2\%) with a mean of $20.8 \mathrm{nmol} / \mathrm{l}$ (range 14.3-24.6) and a mean PTH of $48.3 \mathrm{ng} / \mathrm{l}$ (range 5.0-131.5). A significant inverse correlation between $25(\mathrm{OH}) \mathrm{D}$ and $\mathrm{PTH}$ in control subjects with $25(\mathrm{OH}) \mathrm{D}<25 \mathrm{nmol} / 1 \quad(\mathrm{r}=-0.47 ; \mathrm{p}=0.0013)$ indicated a normal response to vitamin $\mathrm{D}$ deficiency.

Overall, significantly more patients $(18.2 \%)$ than controls $(11.5 \%)$ were taking vitamin D supplementation of $>800 \mathrm{IU} /$ day (800-1500 IU/day) ( $\mathrm{p}=0.04)$ but there was no significant difference in proportions of patients (5.7\%) and controls (8.6\%) taking vitamin D supplementation of 1300-1500 IU/day ( $p>0.05)$. None of the cohort took $>1500 \mathrm{IU}$ vitamin D supplementation/day.

We stratified serum $25(\mathrm{OH}) \mathrm{D}$ results, looking separately at patients and controls not taking vitamin $\mathrm{D}$ supplementation. Mean serum vitamin D level was similar in patients $(38.4 \mathrm{nmol} / \mathrm{l})$ and controls $(37.7 \mathrm{nmol} / \mathrm{l})$ after stratification $(\mathrm{p}>0.05)$. There was no significant difference in mean $25(\mathrm{OH}) \mathrm{D}$ levels between patients $(41.0 \mathrm{nmol} / \mathrm{l})$ and controls $(38.4 \mathrm{nmol} / \mathrm{l})$ who were taking up to $800 \mathrm{IU}$ vitamin $\mathrm{D} /$ day $(\mathrm{p}>0.05)$. The difference was significant only in those with very low levels ('deficiency' $=\leq 25 \mathrm{nmol} / \mathrm{l}$ ), as before, with a greater proportion of MS patients having very low levels $(p=0.004)$.

Mean serum $25(\mathrm{OH}) \mathrm{D}$ levels overall (patients and controls) were significantly lower in those taking no supplements or $<800 \mathrm{IU}$ vitamin $\mathrm{D} /$ day $(38.1 \mathrm{nmol} / \mathrm{l})$ than in those taking $>800$ IU/day $(53.1 \mathrm{nmol} / \mathrm{l})(\mathrm{p}<0.001)$. Mean serum $25(\mathrm{OH}) \mathrm{D}$ were also significantly lower in those taking no supplements or $<1000 \mathrm{IU}$ vitamin $\mathrm{D} /$ day $(39.9 \mathrm{nmol} / \mathrm{l})$ than in those taking $1000-1500 \mathrm{IU} /$ day $(47.9 \mathrm{nmol} / \mathrm{l})(\mathrm{p}=0.03)$. Vitamin D supplement data are displayed in table 4.

Although we did not observe significant relationships between serum $25(\mathrm{OH}) \mathrm{D}$ levels and age at MS onset $(p=0.26)$ or the presence of relapse in the previous 2 years $(p=0.7)$, our data were underpowered to address questions regarding these factors or to comment on any association between MS risk and season of birth, early sun exposure $(2 \mathrm{~h}$ or more of daily summer sun exposure in childhood; $\mathrm{p}=0.21$ ) or vitamin $\mathrm{D}$ supplementation (current or up to age 15 years; $\mathrm{p}=0.76$ ).

\section{Frequency of HLADRB $1 * 15$ allele}

The HLADRB1*15 allele was present in $62.9 \%$ of MS patients compared with $35.2 \%$ of control subjects $(\mathrm{p}<0.01)$. The frequency was significantly higher in Donegal patients $(69 \%)$

Table 2 Population and multiple sclerosis prevalence data in Donegal, Wexford and South Dublin in 2001 and 2007

\begin{tabular}{|c|c|c|c|c|c|c|c|}
\hline Region (latitude) & $\begin{array}{l}\text { Census } \\
1996^{*}\end{array}$ & MS cases 2001 & $\begin{array}{l}\text { Census } \\
2006^{*}\end{array}$ & MS cases 2007 & $\begin{array}{l}\text { Age standardised } \\
\text { prevalence rates: } \\
\text { all MS cases }\end{array}$ & $\begin{array}{l}\text { Age standardised } \\
\text { prevalence rates: } \\
\text { males }\end{array}$ & $\begin{array}{l}\text { Age standardised } \\
\text { prevalence rates: } \\
\text { females }\end{array}$ \\
\hline $\begin{array}{l}\text { Donegal } \\
\left(54^{\circ} 8^{\prime}-55^{\circ} 43^{\prime}\right)\end{array}$ & 129994 & $\begin{array}{l}240 \\
\text { Prevalence: } \\
184.6 / 10^{5} \\
(95 \% \mathrm{Cl} 162.0 \text { to } 209.5)\end{array}$ & 113347 & $\begin{array}{l}329 \\
\text { Prevalence: } \\
290.3 / 10^{5} \\
(95 \% \mathrm{Cl} 238.7 \text { to } 255.5) \\
\mathrm{p}<0.001\end{array}$ & $\begin{array}{l}257.8 / 10^{5} \\
253.2-262.4\end{array}$ & $\begin{array}{l}157.6 / 10^{5} \\
152.7-162.6\end{array}$ & $\begin{array}{l}358.3 / 100000 \\
350.3-366.5\end{array}$ \\
\hline $\begin{array}{l}\text { Wexford } \\
\left(52^{\circ} 2^{\prime}-52^{\circ} 44^{\prime}\right)\end{array}$ & 104372 & $\begin{array}{l}126 \\
\text { Prevalence: } \\
120.7 / 10^{5} \\
(95 \% \mathrm{Cl} 100.6 \text { to } 143.8)\end{array}$ & 119442 & $\begin{array}{l}173 \\
\text { Prevalence: } \\
144.8 / 10^{5} \\
(95 \% \mathrm{Cl} 138.3 \text { to } 151.9) \\
\mathrm{p}>0.05\end{array}$ & $\begin{array}{l}152.0 / 10^{5} \\
148.4-155.6\end{array}$ & $\begin{array}{l}119.0 / 10^{5} \\
114.8-123.4\end{array}$ & $\begin{array}{l}176.0 / 100000 \\
170.4-181.7\end{array}$ \\
\hline $\begin{array}{l}\text { South Dublin } \\
\text { CCA } 1\left(53^{\circ} 17^{\prime}\right)\end{array}$ & 127146 & $\mathrm{~N} / \mathrm{A}$ & 101721 & $\begin{array}{l}130 \\
\text { Prevalence: } \\
127.8 / 10^{5} \\
(95 \% \mathrm{Cl} 131.6 \text { to } 146.7)\end{array}$ & $\begin{array}{l}123.2 / 10^{5} \\
120.0-126.4\end{array}$ & $\begin{array}{l}84.2 / 10^{5} \\
80.6-87.9\end{array}$ & $\begin{array}{l}160.6 / 100000 \\
155.2-166.1\end{array}$ \\
\hline
\end{tabular}


Table 3 Winter serum 25-hydroxyvitamin D levels, winter serum parathyroid hormone levels and HLA-DRB1*1501 frequency in multiple sclerosis patients and control subjects

\begin{tabular}{llllll}
\hline & MS overall & Controls overall & MS Donegal & MS Wexford & MS South Dublin \\
\hline Mean serum 25(OH) D (nmol/l) & 38.57 & 36.41 & 36.90 & 39.71 & 50.74 \\
$\quad$ Range & $13.30-161.90$ & $14.30-97.20$ & $13-97$ & $15-114$ & $13-161$ \\
Mean PTH (ng/l) & 41.07 & 42.04 & 42.93 & 39.94 & 38.95 \\
$\quad$ Range & $14.90-321.70$ & $5-131.50$ & $13-97$ & $18-90$ & $8-39$ \\
\% with HLA-DRB1*1501 & 62.90 & $35.20(\mathrm{p}<0.01)$ & 69 & 63 & 52 \\
\hline
\end{tabular}

25(OH)D, 25-hydroxyvitamin D; HLA, human leucocyte antigen; MS, multiple sclerosis; PTH, parathyroid hormone.

compared with South Dublin patients $(52 \%)(\mathrm{p}<0.04)$. Homozygosity for the HLADRB1*1501-DOB1*0602 haplotype occurred significantly more frequently in Donegal compared with Wexford $(p=0.032)$.

\section{DISCUSSION}

In keeping with recent epidemiological studies of $M S^{3}{ }^{21-23}$ we have observed an increase in the prevalence of MS nationally between 2001 and 2007, with a significant increase in the most northerly region of Donegal. We confirmed the latitudinal gradient found in 2001, ${ }^{23}$ with a significantly greater MS prevalence in the Northwest compared with the Southeast. This latitudinal gradient has been attributed to genetic factors, based on ancestral differences in each area (Celtic in the Northwest and Anglo-Norman in the Southeast) and the heterogeneity in distribution of HLA class II associations (specifically the HLA DRB1*1501-DOB1*0602 haplotype) in between these areas. The ethnic makeup of the study cohort was relatively homogenous. Although Dublin county has experienced significant migration over the past decade, the particular area studied is not an area of marked migration, and population ethnicity was comparable with both Donegal and Wexford. Increased prevalence may be influenced by numerous factors in addition to increased incidence but our case ascertainment and diagnostic techniques have not changed greatly since the last prevalence study in 2001..$^{23}$ Incidence could not be calculated due to inability to ascertain year of (MS) onset data in all identified cases. These particular cases were identified from at least two sources but exact timing of MS onset was not clearly recorded and patients declined interview.

Our study hypothesis is based on the idea that serum vitamin $\mathrm{D}$ levels in adulthood, after MS has presented, are relevant, or at least reflect what has happened previously, a limitation imposed by the nature of our study. Evidence from monozygotic (MZ) twin studies in $\mathrm{MS}^{32}$ supports the hypothesis that $\mathrm{MS}$ is strongly influenced by environmental factors in genetically susceptible individuals, that vitamin D levels are genetically regulated and that $\mathrm{MS}$ itself is not the cause of low vitamin $\mathrm{D}$ (eg, limited sun exposure imposed by indoor lifestyle). Adoptee ${ }^{33}$ step sibling ${ }^{34}$ and half sibling studies ${ }^{35}$ indicate that the environmental component is ubiquitous, rather than limited to the shared family environment. However, the exact timing of vitamin $\mathrm{D}$ action, and whether adult levels reflect those in the

Table 4 Vitamin D supplement doses taken by multiple sclerosis patients and controls

\begin{tabular}{llllll}
\hline Vitamin D3/day & $\mathbf{0}$ & $\mathbf{4 0 0}$ IU & $\mathbf{8 0 0 ~ I U ~}$ & $\begin{array}{c}\mathbf{1 2 0 0 -} \\
\mathbf{1 5 0 0} \mathbf{~ I U}\end{array}$ & $\begin{array}{l}\text { Total } \\
\text { sample }\end{array}$ \\
\hline MS patients (n) (\%) & $204(62.0)$ & $65(19.8)$ & $41(12.5)$ & $19(5.7)$ & $329(100)$ \\
Controls (n) (\%) & $168(74.3)$ & $32(14.2)$ & $6(2.6)$ & $20(8.9)$ & $226(100)$
\end{tabular}

Of note, standard multivitamins, usually containing only $400 \mathrm{IU} /$ day, are unlikely to alter serum levels of vitamin $D$.

IU, international units; MS, multiple sclerosis past, is as yet unknown. Chronic low concentrations, seasonal fluctuation or acute effects may all increase risk, and this limits our ability to draw clear conclusions. Insufficient pre- and perinatal vitamin $\mathrm{D}$ levels may imprint on functional characteristics of various tissues, increasing the risk of adult onset MS by interacting with other genetic susceptibility factors ${ }^{36}$ and adult exposures (including hypovitaminosis D during adult life).

MS displays a month of birth effect, with an excess of patients being born in spring and a deficit in winter; the effect is most pronounced in familial cases, ${ }^{37}$ implicating interactions between genes and environment related to climate. A recent Scottish study ${ }^{38}$ showed a marked difference (50\%) in MS risk between being born in April versus November, and this month of birth association implicates interaction of a seasonal risk factor with loci at or near HLA-DRB1, the region exerting the single strongest genetic effect in MS, during gestation or shortly after birth. ${ }^{39}$ Our study was not sufficiently powered to address month of birth. The nature of this timing of birth effect remains unknown but maternal vitamin $\mathrm{D}$ deficiency is one plausible candidate. ${ }^{37} 4036$

Although MZ twins share a common genotype, epigenetic differences may cause phenotypic discordance (including disease susceptibility). Examination of differences in DNA methylation and histone acetylation in a large cohort of $M Z$ twins $^{41}$ showed that, although epigenetically indistinguishable during the early years of life, marked differences in content and genomic distribution of 5-methylcytosine DNA and histone acetylation in older twins affected their gene expression portrait. The divergence of epigenetic modification patterns with age may be influenced by intrinsic and extrinsic factors, such as smoking and diet, and epigenetic drift may occur with ageing itself. Fraga et al showed that approximately one-third of twins studied displayed epigenetic differences in DNA methylation and histone modification, distributed throughout their genomes and impacting on gene expression. These markers were more distinct in older twins with different lifestyles, highlighting the role of environmental factors in modifying a common genotype to a different phenotype (eg, discordant MS onset in MZ twins). Environmental modulation of genetic information, by altering the pattern of epigenetic modifications, supports the environment (vitamin D)-genetic interaction findings in our study, and suggests that adult exposures, including vitamin $\mathrm{D}$ levels, may play a role in both MS risk and disease modification, even if the critical exposure period began prenatally.

Despite our hypothesis that the prevalence gradient would relate to lower $25(\mathrm{OH}) \mathrm{D}$ in $\mathrm{MS}$ patients, $25(\mathrm{OH}) \mathrm{D}$ levels between the north (Donegal) and south (Wexford) were not significantly different and did not differ from control subjects; winter levels were low in all participants. It is important to remember that optimal levels remain undefined (and may be much higher than current laboratory reference ranges-for example, $\geq 100 \mathrm{nmol} / \mathrm{l}){ }^{42}$ Our view of sufficiency is arbitrary, and we cannot assume that all individuals require the same 
levels. However, mean winter levels in our Irish cohort were low overall $(<50 \mathrm{nmol} / \mathrm{l})$ and significantly more MS patients than controls had very low levels $(<25 \mathrm{nmol} / \mathrm{l})$. As previously described by others, ${ }^{15}$ there was a blunted PTH response only in MS patients with vitamin D deficiency $(<25 \mathrm{nmol} / \mathrm{l})$ but its meaning is unclear. Only a small percentage took $>1000 \mathrm{IU}$ vitamin D3 daily; maximum intake was $<1500$ IU but it is likely that at least 4000 IU daily are required to achieve levels of $100 \mathrm{nmol} / \mathrm{l}^{43}$ Despite differences in solar radiation (UV-B) exposure between areas, the northwest of Ireland experiences on average 319875 joules $/ \mathrm{cm}^{2}$ solar radiation annually compared with 331683 joules $/ \mathrm{cm}^{2}$ solar radiation in the southeast ${ }^{44}$; it is probable that the latitudinal range in a small country such as Ireland is insufficient to demonstrate such an effect. Higher 25 $(\mathrm{OH}) \mathrm{D}$ in southeast Dublin may be genetically regulated or relate to more widespread use of vitamin D supplements (39\%) compared with Wexford (24\%), and greater availability and consumption of fortified milk in Dublin. ${ }^{45}$ Differences in socioeconomic group distribution between these areas may influence supplementation practices. ${ }^{27}$ However, in $52 \%$ of patients and $55 \%$ of controls taking vitamin D3 supplements, the dose of $\leq 400 \mathrm{IU} /$ day was unlikely to alter serum levels significantly.

The HLA DRB1*15 allele, associated with MS susceptibility, was significantly overrepresented in MS patients compared with controls, and HLA-DRB1*15 frequency was significantly lower in southeast Dublin compared with areas of higher MS prevalence. Active vitamin D (1, 25-dihydroxyvitamin D) binds the intranuclear vitamin $\mathrm{D}$ receptor (VDR) whose gene locates to chromosome 12q13.1. The resulting complex binds the retinoid $X$ receptor ( $R X R)$, resulting in a VDR-RXR complex, which then binds the vitamin D response element (VDRE). ${ }^{46}$ Recently, a VDRE was found on HLA DRB1*1501, the major MS susceptibility allele. Insufficient HLA DRB1*1501 expressionin the setting of low vitamin $\mathrm{D}$ and suboptimal binding to the VDRE, with poor upregulation of HLA DRB1*1501-could affect central deletion of autoreactive $\mathrm{T}$ cells. Thus people possessing HLA DRB1*1501 may be at high risk of autoimmunity (MS) in the setting of vitamin D deficiency and this combination may explain the high prevalence of MS in the Irish population.

The latitudinal variation in MS in Ireland is not explained by $25(\mathrm{OH}) \mathrm{D}$ levels alone but most likely the interaction with genetic susceptibility. In a gene-environment interaction, lacking either component can prevent clinical expression of disease, leaving one factor apparently unrelated to risk when both are required. Therefore, similar overall serum $25(\mathrm{OH}) \mathrm{D}$ levels in patients and controls does not outrule the role of low vitamin $\mathrm{D}$ in $\mathrm{MS}$ pathogenesis in our cohort.

In addition to the previously discussed limitation imposed by the nature of our study (ie, hypothesis based on the idea that serum vitamin $\mathrm{D}$ levels in adulthood are relevant in $\mathrm{MS}$ ), we acknowledge that inclusion of spouses as controls is not always ideal, as they are usually in the same environment as affected cases and may modify their risk by taking vitamin $\mathrm{D}$ supplements more readily. However, we found that significantly more patients $(18.2 \%)$ than controls $(11.5 \%)$ were taking vitamin $\mathrm{D}$ supplements ( $\geq 800 \mathrm{IU})(\mathrm{p}=0.04)$, despite this potential spousal influence. Spousal controls were included because they were more willing to give samples than people without affected family or partners.

In conclusion, although unproven, one might hypothesise that combined high frequency of HLADRB1*15 and widespread vitamin $\mathrm{D}$ insufficiency may explain the high, increasing $\mathrm{MS}$ prevalence in the Irish population. Vitamin D may only be one factor in a common mechanism by which environment interacts but it is a potentially modifiable risk. Vitamin D insufficiency is common throughout the population, an important public health observation. The MS prevalence gradient in Ireland is not explained by variation in $25(\mathrm{OH}) \mathrm{D}$ levels alone but differences in the frequency of the MS risk allele HLADRB1*1501 and risk haplotype HLADRB1*1501-DOB1*0602 combined with low serum vitamin $\mathrm{D}$ levels probably influence latitudinal variation

Acknowledgements The authors would like to thank sincerely the consultant neurologists Dr R Murphy and Dr D McCabe at AMNCH, Tallaght, Dr J Redmond and Dr C Doherty at St James' Hospital, Professor 0 Hardiman, Dr N Delanty and Dr J Moroney at Beaumont Hospital, Professors T Lynch and P Kelly at the Mater Misericordiae hospital in Dublin, Dr K Murphy at Sligo General Hospital and Dr Peter Boers at the Western Regional Hospital, Limerick, Dr P Crowley at Waterford Regional Hospital, Dr D Costigan, Dr H Galvin and also the general practitioners in each region, for granting access to data of MS patients in our study areas. We would also like to thank Dr Bannan, Consultant Physician at Letterkenny Hospital and Dr Quigley Consultant Physician at Wexford General Hospital, who allowed us to use their clinic rooms for weekend research clinics. We are also grateful to MS Ireland for much help during the study, and for ongoing support. We also thank the patients with MS and the control volunteers who agreed to participate in this study.

Funding MS Ireland contributed funds towards the study.

\section{Competing interests None}

Ethics approval This study was conducted with the approval of the ethics committee of St Vincent's University Hospital, Dublin, Ireland.

Provenance and peer review Not commissioned; externally peer reviewed.

\section{REFERENCES}

1. Peltonen L. Old suspects found guilty - the first genome profile of multiple sclerosis. N Engl J Med 2007;357:927-9.

2. Dunne C, McGuigan C, Crowley J, et al. Human leucocyte antigen class II polymorphism in Irish paients with multiple sclerosis. Tissue Antigens 2006:68:257-62.

3. Ebers GC. Environmental factors and multiple sclerosis. Lancet Neurol 2008;7:268-77.

4. Gilli $\mathbf{F}$, Valentino $P$, Caldano $M$, et al. Expression and regulation of IFN $\alpha / \beta$ receptor in IFN $\beta$ - treated patients with multiple sclerosis. Neurology 2008;71:1940-7.

5. Acheson ED, Bachrach CA, Wright FM. Some comments on the relationship of the distribution of multiple sclerosis to latitude, solar radiation, and other variables. Acta Psychiatr Scand 1960;(Suppl 35):132-47.

6. Kurtzke JF, Beebe GW, Norman JE, et al. Epidemiology of multiple sclerosis in U.S veterans: 1. Race, sex, and geographic distribution. Neurology 1979;35

7. Miller DH, Hammond SR, McLeod JG, et al. Multiple sclerosis in Australia and New Zealand: are the determinants genetic or environmental? J Neurol Neurosurg Psychiatry 1990;53:903-5.

8. Ascherio A, Munger KL. Environmental risk factors for multiple sclerosis, part I: the role of infection. Ann Neurol 2007;61:288-99.

9. Pugliatti M, Sotgiu S, Rosati G. The worldwide prevalence of multiple sclerosis Clin Neurol Neurosurg 2002;104:182-91.

10. Munger KL, Levin LI, Hollis BW, et al. Serum 25-hydroxyvitamin D levels and risk of multiple sclerosis. JAMA 2006;296:2832-8.

11. Dean G, Elian M. Age at immigration to England of Asian and Caribbean immigrants and the risk of developing multiple sclerosis. J Neurol Neurosurg Psychiatry 1997:63:565-8.

12. Hammond SR, English DR, McLeod JG. The age-range of risk of developing multiple sclerosis: evidence from a migrant population in Australia. Brain 2000;123(Pt 5):968-74.

13. Beretich and Beretich. Explaining multiple sclerosis prevalence by ultraviole exposure: a geospatial analysis. Mul Scler 2009;15:891-8.

14. McKenna MJ. Differences in vitamin D status between countries in young adults and the elderly. Am J Med 1992;93:69-77.

15. Soilu-Hanninen $\mathbf{M}$, Laaksonen M, Laitinen I, et al. A longitudinal study of serum 25-hydroxyvitamin D and intact PTH levels indicate the importance of vitamin $D$ and calcium homeostasis regulation in multiple sclerosis. J Neurol Neurosurg Psychiatry 2008;79:153-7.

16. Hayes CE, Nashold FE, Spach KM, et al. The immunological function of the vitamin D endocrine system. Mol Cell Biol 2003;49:277-300.

17. Correale J, Ysrraelit MC, Gaitan Ml. Immunomodulatory effects of vitamin D in multiple sclerosis. Brain 2009:132:1146-60.

18. The Australia and New Zealand Multiple Sclerosis Genetics Consortium (ANZgene). Genome-wide association study identifies new multiple sclerosis susceptibility loci on chromosomes 12 and 20. Nat Genet 2009;41:824-8. 
19. Auer DP, Schumann EM, Kumpfel T, et al. Seasonal fluctuations of gadoliniumenhancing magnetic resonance imaging lesions in multiple sclerosis. Ann Neurol 2000;47:276-7.

20. Embry AF, Snowdon LR, Vieth R. Vitamin D and seasonal fluctuations of gadoliniumenhancing magnetic resonance imaging lesions in multiple sclerosis. Ann Neurol 2000:48:271-2

21. Alvaro A, Hernán MA. Temporal trends in the incidence of multiple sclerosis A systematic review. Neurology 2008;71:129-35.

22. Gray $\mathbf{O M}, \mathbf{M c D o n n e l l} \mathrm{GV}$, Hawkins SA. Factors in the rising prevalence of multiple sclerosis in the north-east of Ireland. Mult Scler 2008;14:880-6.

23. McGuigan C, McCarthy A, Quigley $\mathrm{C}$, et al. Latitudinal variation in the prevalence of multiple sclerosis in Ireland, an effect of genetic diversity. J Neurol Neurosurg Psychiatry 2004;75:572-6.

24. Lublin FD, Reingold SC. Defining the clinical course of multiple sclerosis: results of an international survey. National Multiple Sclerosis Society (USA) Advisory Committee on Clinical Trials of New Agents in Multiple Sclerosis Neurology 1996:46:907-11.

25. Kurtzke JF. Rating neurologic impairment in multiple sclerosis: an expanded disability status scale (EDSS). Neurology 1983;33:1444-52.

26. Polman CH, Reingold SC, Edan GE, et al. Diagnostic Criteria for multiple sclerosis: 2005 revisions to the "McDonald Criteria". Ann Neurol 2005;58:840-6.

27. Central Statistics Office Ireland. 2006. CSO Central Statistics Office, Skehard Road, Cork, Ireland. webmaster@cso.ie.

28. Van der Mei IAF, Ponsonby A-L, Dwyer T, et al. Past exposure to sun, skin phenotype, and risk of multiple sclerosis: case-control study. BMJ 2003;327:316.

29. McKenna MJ, Freaney R. Secondary hyperparathyroidism in the elderly: means to defining hypovitaminosis D. Osteoporos Int 1998;8(Suppl 2):S3-6.

30. Holick M. Vitamin D deficiency. N Engl J Med 2007:357:266-81.

31. Abramson JH. WINPEPI (PEPI-for-Windows): computer programs for epidemiologists. Epidemiol Perspect Innovations 2004;1:6.

32. Sarah-Michelle 0, Andrew PM, Blanca MH, et al. Evidence for genetic regulation of vitamin D status in twins with multiple sclerosis. Am J Clin Nutr 2008;88:441-7.
33. Ebers GC, Sadovnick AD, Risch NJ. A genetic basis for familial aggregation in multiple sclerosis. Canadian Collaborative Study Group. Nature 1995;377:150-1.

34. Dyment DA, Yee IM, Ebers GC, et al. Multiple sclerosis in stepsiblings: recurrence risk and ascertainment. J Neurol Neurosurg Psychiatry 2006:77:258-9.

35. Ebers GC, Sadovnick AD, Dyment DA, et al. Parent-of-origin effect in multiple sclerosis: observations in halfsiblings. Lancet 2004;363:1773-4.

36. Ramagopalan SV, Maugeri NJ, Handunnetthi $L$, et al. Expression of the multiple sclerosis-associated MHC class ii allele HLA-DRB1*1501 is regulated by vitamin D. PLoS Genet 2009:5:1-6.

37. Willer CJ, Dyment DA, Sadovnick $A D$, et al. Timing of birth and risk of multiple sclerosis: population based study. BMJ 2005;330:120.

38. Bayes HK. Weir CJ, O'Leary C. Timing of birth and risk of multiple sclerosis in the Scottish population. Eur Neurol 2010;63:36-40.

39. Ramagopalan SV, Link J, Byrnes JK, et al. HLA-DRB1 and month of birth in multiple sclerosis. Neurology 2009;73:2107-11.

40. Looker AC, Dawson-Hughes B, Calvo MS, et al. Serum 25-hydroxyvitamin D status of adolescents and adults in two seasonal subpopulations from NHANES III. Bone 2002;30:771-7.

41. Fraga MF, Ballestar E, Paz MF, et al. Epigenetic differences arise during the lifetime of monozygotic twins. PNAS 2005;102:10604-9.

42. Bischoff-Ferrari HA, Giovannucci E, Willett WC, et al. Estimation of optimal serum concentrations of 25-hydroxyvitamin D for multiple health outcomes. Am J Clin Nut 2006;84:18-28.43?

43. Vieth R. Vitamin D supplementation, 25-hydroxyvitamin D concentrations, and safety. Am J Clin Nutr 1999;69:842-56.

44. Met Eireann 2009 (Meteorology Ireland). Met Eireann, Glasnevin Hill, Dublin 9. met.eireann@met.ie.

45. McKenna MJ, Freaney R, Byrne P, et al. Safety and efficacy of increasing wintertime vitamin $\mathrm{D}$ and calcium intake by milk fortification. $0 \mathrm{~J} \mathrm{Med}$ 1995;88:895-8.

46. Smolders $\mathbf{J}$, Damoiseaux $J$, Menheere $\mathrm{P}$, et al. Vitamin $\mathrm{D}$ as an immune modulator in multiple sclerosis, a review. J Neuroimmunology 2008;194:7-17. 